\title{
A SHORT PROFILE ON TRIANTHA (NUTT.) BAKER WITH A FOCUS ON T. OCCIDENTALIS (S.WATSON) R.R. GATES
}

BARRY A. RICE $\bullet$ Center for Plant Diversity $\bullet$ University of California $\bullet$ One Shields Avenue $\bullet$ Davis

- California 95616•USA • brice@sierracollege.edu

Keywords: Taxonomy: Triantha occidentalis.

Introduction, taxonomy, and ranges

In case you haven't heard, a recent study (Lin et al. 2021) has revealed that Triantha occidentalis is carnivorous. This is remarkable news for a number of reasons. First, Triantha is a monocot, and carnivory in monocots is a very rare thing indeed. Second, those few monocots that are carnivorous, are quite unimpressive in their carnivorous nature - for the most part they are only urn-forming bromeliads that passively capture prey (see the discussions of Brocchinia and Catopsis in McPherson 2007). Triantha is different... it is a monocot with glandular hairs, the glandular hairs release digestive enzymes, and the plant absorbs the nutrients from the captured prey into its own tissues!

What follows is a short introduction to this attractive plant, including information about this plant's closest relatives, where it grows, how to identify it in the field, some notes about its natural history and conservation status, and a little speculation about its horticulture.

There is some disagreement in how scientists organize plant relationships, and we see this here. In the Flora of North America (Packer 1993), the genus Triantha is classified as being in the lily family (Liliaceae). Meanwhile, in the Jepson eFlora-which is the most commonly used taxonomic authority in California-Triantha is placed in the false asphodel family (Tofieldiaceae; see McNeal 2012). I follow the Jepson eFlora in this respect, as did the Lin et al. (2021).

There are four genera in the Tofieldiaceae: Harperocallis McDaniel, Pleea Michx., Tofieldia Huds, and Triantha (Nutt.) Baker. It would be fair to say that none of these plants are particular beauties that would make the average vacationer stop their car to gawk, but after giving the plants some time to be appreciated, the astute naturalist will see that these are quite lovely.

The genus Triantha has four species. (Triantha occidentalis was formerly classified as Tofieldia occidentalis.) Three of them are found only in North America (the USA and Canada), while one is restricted to Japan. Their ranges are below (GBIF 2021; Packer 1993).

Triantha glutinosa (Michaux) Baker: Found in Canada and northern USA - In Canada: all the geographical regions except Nunavut; in the USA: OR, ND, MN, WI, MI, IL, IN, OH, WV, VA, NT, NC, NV, VT, NH, ME, AK.

Triantha japonica (Miq.) Baker: Only found in Japan (Chūgoku northwards to Hokkaidō).

Triantha occidentalis (S.Watson) R.R.Gates: Found in Canada and northern USA-In Canada: BC, AB; in the USA: AK, WA, ID, MT, WY, OR, CA.

Triantha racemosa (Walter) Small: Found in southeastern USA: TX, LA, MS, AL, FL, GA. Also occurs along the Mid-Atlantic coast: VA, DE, DC, MD. Populations in New Jersey may be hybrids with T. glutinosa (Packer 1993).

The species Triantha occidentalis has three subspecies: Triantha occidentalis subsp. occidentalis, Triantha occidentalis subsp. brevistyla (C.L.Hitchc.) Packer, and Triantha occidentalis subsp. montana (C.L.Hitchc.) Packer. The ranges of these three subspecies are as follows. 
Triantha occidentalis subsp. occidentalis: USA (OR, CA)

Triantha occidentalis subsp. brevistyla: Canada (BC, AB), USA (AK, ID, WA, OR)

Triantha occidentalis subsp. montana: Canada (BC, AB), USA (AK, ID, MT, WY)

In California, the plant is found mostly in three large range segments. The first range segment is the northwest portion of the state (especially the Klamath Ranges). The second and third range segments are in the Sierra Nevada, ranging from Lassen Volcanic National Park southwards to (and somewhat past) Sequoia and Kings Canyon National Parks. This long range is divided into two segments by an apparent absence of occurrences in Alpine, Amador, and Calaveras Counties. Other reports exist for this plant in Sonoma County and Marin County, although the ones from Sonoma County are quite old (1928-1972) and in regions that have experienced significant habitat modification.

The authors in Lin et al. (2021) treated Triantha occidentalis at the species level, and did not comment on possible differences in carnivory at a subspecific level. Their field work used specimens of Triantha occidentalis subsp. brevistyla (Lin, pers. comm. 2021) from Cypress Provincial Park, British Columbia, Canada. In their illustrations they included supporting imagery of Triantha occidentalis subsp. brevistyla from North Cascades National Park in Washington (USA), but also Triantha occidentalis subsp. occidentalis from California (USA). The inference would be that the authors consider carnivory to be the case throughout the species.

\section{Identifications}

There are many monocots with basal rosettes of long leaves, and which have white flowers on racemes, so I will not give here comprehensive guidelines to identify which of these are Triantha. But in my region (California), if you find such a plant, and you further observe that it has superior ovaries and three styles, six more or less similar tepals that are not fused to each other, and filaments that are glabrous, it is very likely you are looking at Triantha. Confirm the identification in your local flora!

Some additional hints follow. Consider range...that might make your identification easy. Cultivated plants (or those in range overlap zones) present more challenges, and in such cases you will need plants in flower (and perhaps fruit).

First, let us identify the three plants in the genus to species. Triantha racemosa is easiest to distinguish from the others - its three styles are fused from their bases upwards for $1 / 4$ to $2 / 3$ their length, while the styles of T. occidentalis and T. glutinosa are distinct.

It is more difficult to tell $T$. occidentalis from $T$. glutinosa. The easiest metric is to look for a white seed coat that encloses the dark reddish seed - this coat is present on T. occidentalis, but absent on T. glutinosa. Lacking seeds, look for long glandular hairs just below the inflorescence, or a globose shape to the inflorescence: Triantha glutinosa lacks long glandular hairs or globose flower heads, while (depending on the subspecies) these characters may be expressed in T. occidentalis.

If you are confident that you have Triantha occidentalis, you should try to identify it to subspecies. Our current understanding of the subspecies indicates overlapping ranges for subsp. brevistyla with subsp. montana, and subsp. brevistyla with subsp. occidentalis. Reproducing (stealing!) the key from Flora of North America (http://floranorthamerica.org/Triantha_occidentalis) indicates a number of useful features:

1a. Seed coat not strongly inflated; seeds 3-4 times longer than wide; stems coarsely glandularpubescent with cylindrical hairs below inflorescence, hairs 4-6 times longer than wide, or glands absent $\rightarrow$ Triantha occidentalis subsp. montana 
1b. Seed coat strongly inflated; seeds usually 1-2(-3) times longer than wide; stems glandularpubescent below inflorescence, with glands $1 / 2-2$ times longer than wide, or pubescent with cylindrical hairs 2-4 times longer than wide, sometimes glands and hairs intermixed $\rightarrow 2$

2a. Styles 0.6-1.5 mm; inflorescences usually cylindrical-ovoid $\rightarrow$ Triantha occidentalis subsp. brevistyla

2b. Styles 1.3-3 mm; inflorescences usually globose $\rightarrow$ Triantha occidentalis subsp. occidentalis

With some practice and appropriate materials, these key features should be reliably diagnostic. The only complications that have been found is that T. occidentalis subsp. occidentalis and T. occidentalis subsp. brevistyla might intergrade in southwest Oregon (Packer 1993). Furthermore, $T$. occidentalis subsp. occidentalis in Del Norte County (California) and Josephine County (Oregon) might be atypically large, with elongate inflorescences (Packer 1993; pers. obs.).

\section{Natural history and conservation}

Triantha occidentalis produces a rosette of linear, basal leaves up to $50 \mathrm{~cm}$ tall and nearly $1 \mathrm{~cm}$ wide. Each inflorescence is a single, naked scape up to $80 \mathrm{~cm}$ tall (Fig. 1A). It reportedly can bear a
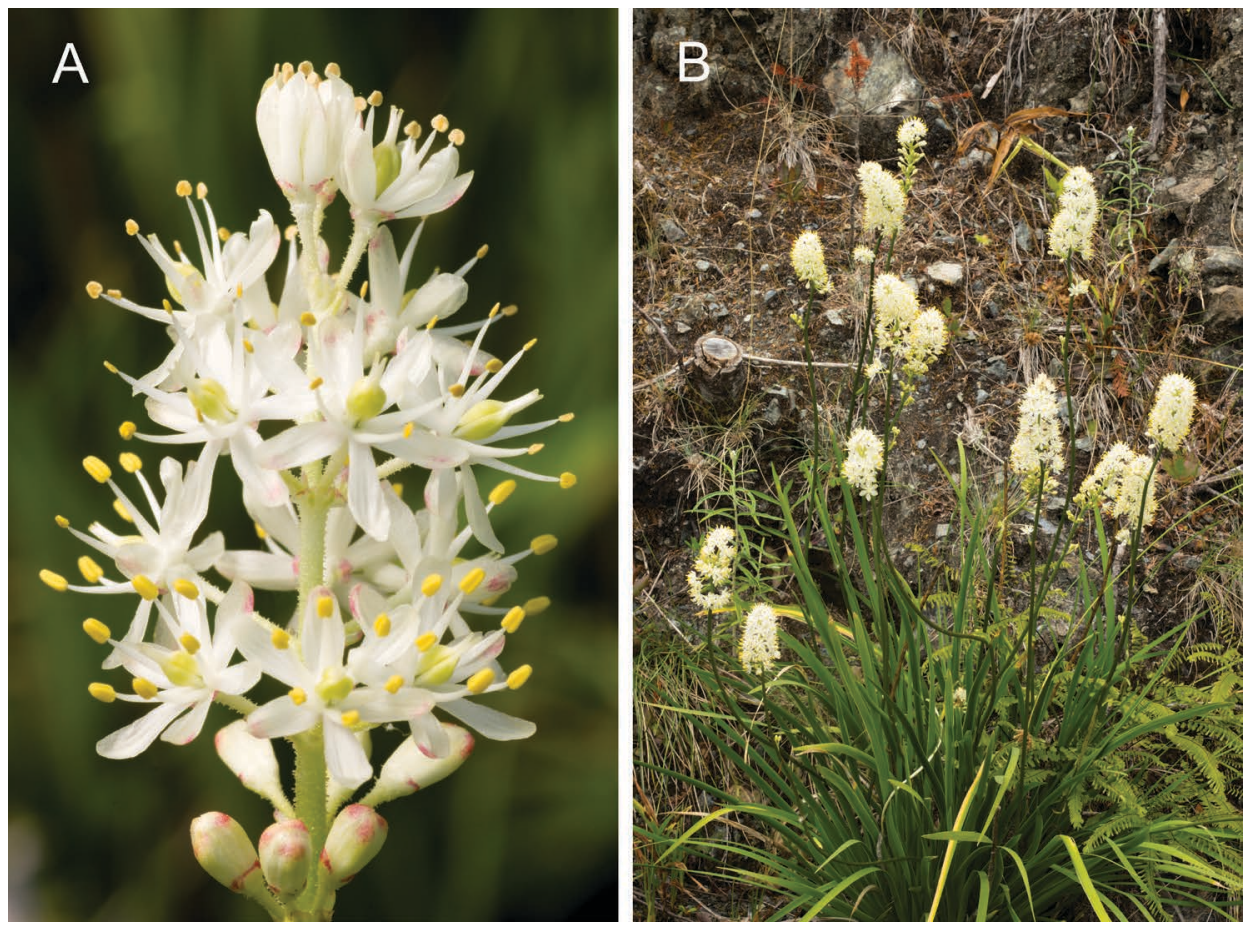

Figure 1: (A): Triantha occidentalis subsp. occidentalis in Plumas County (California). Can you see the small, glandular hairs on the inflorescence, and also can you see the groupings of flowers in threes? (B): Triantha occidentalis subsp. occidentalis in Del Norte County (California). The inflorescences of these plants are so large, they start to look like Toxicoscordion (=Zigadenus), in the closely related family Melanthiaceae. 
few leaves on it, but I have not yet observed this. Each plant can produce a number of inflorescences. The flowers are clustered near the top of the inflorescence in a fairly dense cluster. This cluster is usually globose, but elongated clusters are to be expected, especially near the Oregon-California border (Fig. 1B). The flowers tend to be produced in little clusters of three flowers, which is the origin of the name Triantha.

The flowers have six blunt tipped tepals (the three sepals and three petals are, to my eye, nearly identical) 3-7 mm long. The filaments are white, stout, and nearly as long as the tepals. The anthers are bright yellow. The elongate superior ovary is topped by three distinct styles. The inflorescence bears short, stalked glands, which is of course why you are reading about the plant in this journal. Fruit are capsules that bear reddish brown seeds about $1 \mathrm{~mm}$ long, encased in a white coat. The fruit can become tinged with red, and are sometimes more eye-catching than the flowers!

I have never had any reason to dig around a plant, but it reportedly has short spreading rhizomes, and as such probably can reproduce vegetatively by natural division.

I have seen it growing in full sun and partial shade. In California I have found it in wet seepages, wet meadows, floating sphagnum bogs, or riparian areas (Fig. 2). I have found growing at carnivorous plant sites that contain Darlingtonia californica, Drosera anglica, Drosera rotundifolia, Drosera $\times$ obovata, Pinguicula macroceras, Utricularia macrorhiza, Utricularia intermedia, Utricularia ochroleuca, and Utricularia minor), but it is certainly not picky. It is even reported in non-wetlands (Calflora 2021).

In California, it flowers over a long season (depending upon altitude and exposure of the site), typically from July through September (Calflora 2021).

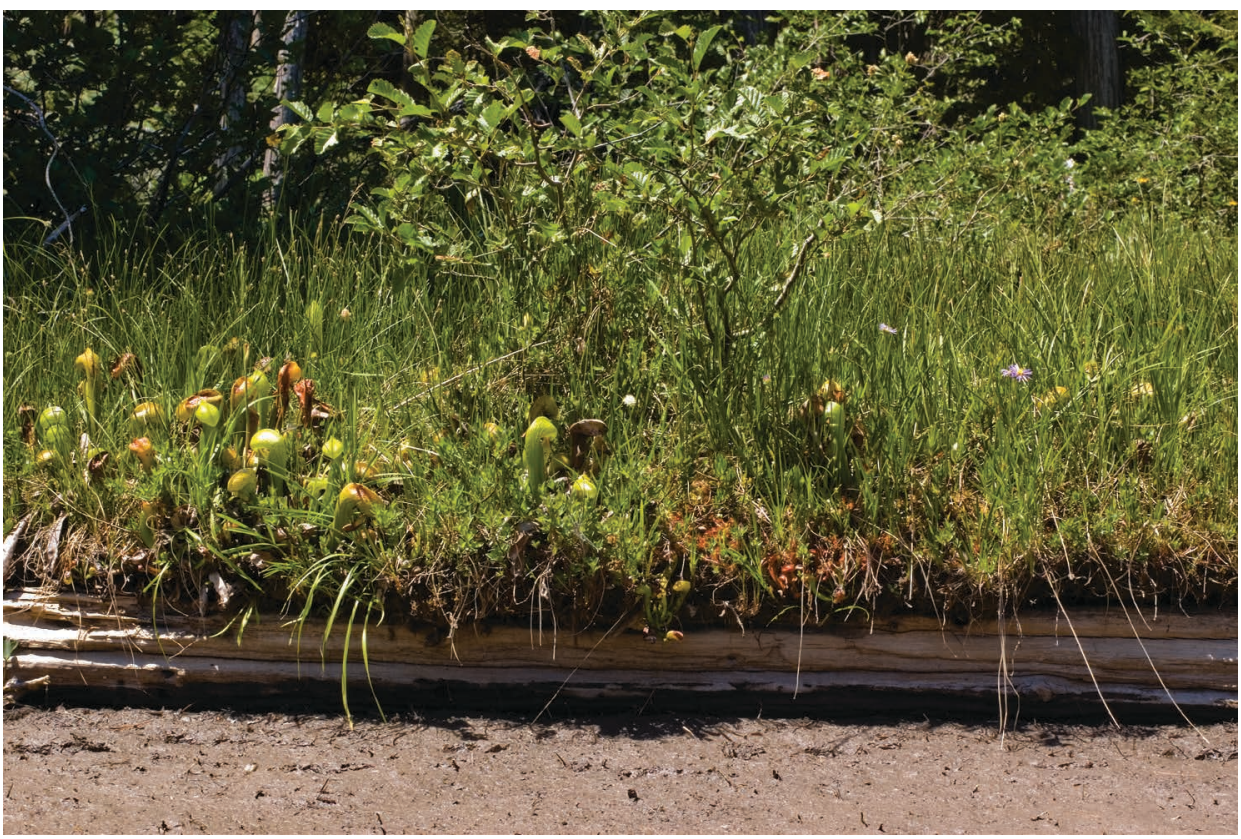

Figure 2: Can you see it? In the photo center, there is a single rounded head of Triantha occidentalis subsp. occidentalis in this Siskiyou County (California) Darlingtonia and Drosera rotundifolia lakeside habitat. There's also Utricularia macrorhiza and Utricularia minor present, but not visible in the photo. 
In terms of conservation status, Triantha does not appear on any rarity lists, either state or globally. It has a wide range, and occurs in many sites in the wild. That said, I expect the extraordinary fire seasons we are now experiencing in the western USA, exacerbated by global climate change, will significantly impact many wetland sites. Even if the sites do not themselves burn, they may be subject to harmful impacts because of post-fire sedimentation and overall changes in hydrology.

As yet, poaching is not an issue. Unfortunately, I know the culture of carnivorous plant horticulturists, and the presence of bad apples, and fully expect to start hearing about plants being dug from the wild. I would strongly discourage against such practices. If collection is to be done, collect seeds within the framework of state and local laws, please.

\section{Guesses on cultivation}

This is not a particularly showy plant, and is unlikely to be encountered for sale except by native plant specialty nurseries. Looking online, I have only found one source for seeds, which recommends a cold, wet stratification period of 60-90 days (Klamath-Siskiyou Native Seeds 2021).

I suspect that this plant is not particularly challenging to grow, if you followed a general cultivation method appropriate for carnivorous plants such as Sarracenia or Darlingtonia. I would try a low nutrient, neutral to acidic $\mathrm{pH}$ medium. Remember that it grows outside in an area with significant winter snowfall, so give it a good cold rest.

It is likely that this plant will divide naturally via rhizome multiplication. I have seen multipleheaded plants in the wild, and suspect that they resulted from natural division.

This is all new terrain, and it will be interesting to see the results, as carnivorous plant growers turn their attention towards cultivating this plant. Does it require cross pollination? Is stratification really necessary? Will it respond well to fertilization? Will it turn out to be an inexplicably difficult plant to grow? Time will tell. But please... do make sure you obtain your plant propagules responsibly. I challenge growers not to field collect plants!

\section{References}

Calflora. 2021. Information on wild California plants. Berkeley, California: The Calflora Database. https://www.calflora.org. Accessed 25 August 2021.

GBIF. 2021. Triantha japonica (Miq.) Baker. Global Biodiversity Information Facility (GBIF) Secretariat 2021. https://www.gbif.org/species/2864312. Accessed 25 August 2021.

Klamath-Siskiyou Native Seeds. 2021. https://klamathsiskiyouseeds.com. Accessed 25 August 2021.

Lin, Q., Ané, C., Givnish, T.J., and Graham, S.W. 2021. A new carnivorous plant lineage (Triantha) with a unique sticky-inflorescence trap. PNAS. 118 (33) e2022724118. https://doi.org/10.1073/ pnas.2022724118. Accessed 25 August 2021.

McPherson, S. 2007. Pitcher Plants of the Americas. The McDonald \& Woodward Publishing Company. Blacksburg, Virginia. 320 p.

McNeal, D.W. 2012. Triantha, in Jepson Flora Project (eds.) Jepson eFlora. https://ucjeps.berkeley. edu/eflora/eflora_display.php?tid=89271. Accessed 25 August 2021.

Packer, J.G. 1993. Triantha. In: Flora of North America Editorial Committee, eds. 1993+. Flora of North America North of Mexico [Online]. 22+ vols. New York and Oxford. Vol. 3. http://floranorthamerica.org/Triantha. Accessed 25 August 2021. 